\title{
GENETIC PARAMETERS AND BREEDING VALUES FOR PRODUCTIVE REPRODUCTIVE AND PERSISTENCY OF MILK YIELD TRAITS OF CULLED COWS AND THEIR CONTEMPORARIES RETAINED IN HERD OF FRIESIAN CATTLE AT DIFFERENT LACTATIONS. Mostafa, M.A. \\ Department of Animal Production, Fac. of Agriculture, Mansoura University, PC: 35516, Mansoura, Egypt.
}

\begin{abstract}
Records of production, reproductive and persistency of milk yield performance of Holstein Friesian cows kept at Mezoheges State Farm, Hungary collected during the period from 1982 to 1990 were used. These were either culled after completing a particular lactation $(n=2219)$ or retained to give subsequent lactations up to the $4 \frac{\text { th }}{n}$ lactation, $(n=4138)$. Data were analysed to estimate genetic parameters breeding values and to compare the productive and reproductive performance between the two groups. The data covered milk production traits: total milk yield (TMY), 305-day milk yield (305-d MY), 305-day fat yield (305-d FY) and persistency of milk yield (Pr MY) and reproductive traits: number of services per conception (NSC) and days open (DO).

The results obtained could be summarized as follows:

- The actual means of TMY, 305-d MY, 305-d FY, Pr MY, NSC and DO were 7197, $6974,255 \mathrm{~kg}, 72.71 \%, 2.23$ services and 125.8 day, respectively, across 1 st four lactations. Coefficients of variation (CV\%) of milk production traits ranged from 25.08 to $34.00 \%$, but for Pr MY was $13.45 \%$, while for NSC and DO were 73.99 and $63.56 \%$, respectively.

- The estimates of heritability + S.E of the 1 st lactation based on animal model method for TMY, 305-d MY, 305-d FY, Pr MY, NSC and DO were $0.31 \pm 0.05,0.35 \pm$ $0.05,0.30 \pm 0.04,0.10 \pm 0.03,0.12 \pm 0.03$ and $0.09 \pm 0.03$, respectively

- Estimates of $r_{g}$ and $r_{p}$ correlations between production and reproduction traits were positive and medium to high ranged from $0.58 \pm 0.12$ to $0.91 \pm 0.05$ and from 0.24 to 0.50 , respectively. Also estimates of $r_{g}$ correlation between $\operatorname{Pr} M Y$ and each of NSC and DO were $0.21 \pm 0.15$ and $0.12 \pm 0.11$, while $r_{p}$ were 0.07 and 0.08 respectively.

- Culling rate increased with advance of parity, being 26.3 and $49.2 \%$ at the end of the $1^{\text {st }}$ and $4^{\text {th }}$ lactations, respectively. Culled cows had significantly higher TMY, 305-d MY, 305-d FY and Pr MY than those retained and the differences between the two groups were generally more pronounced in the 1 st two lactations. Culled cows had also significant larger NSC and longer DO than retained cows. These results showed that the culled cows have lower reproductive performance and higher milk production traits than those retained in the herd.

- The range in estimates of breeding values of animals for all traits studied for both retained and culled cows was wide, suggesting that there is scope for selection.

- The results indicated that more attention should be given to high yielding cows, particularly their reproductive management, to increase their longevity and hence improve herd productivity. Moreover, culling decisions have an important influence on the economic performance of the dairy but are must be based on the EBVs for economic traits.
\end{abstract}

Keywords: Holstein Friesian, genetic parameters, culling rate, milk yield traits, reproductive traits, breeding value. 


\section{INTRODUCTION}

The dairy animals breeders look to the milk yield, fertility and health as the most important traits influence the profitability of dairy production. Also, the role of longevity must be consider in the profitability evaluation of the dairy herds (Brotherstone et al., 1997). The longevity may be defined from different side of views as the ability to avoid death or culling, the former being mostly from diseases or accident and the latter from reproductive failure, low milk yield, mastitis, etc. Culling is the act of removing a cow from a herd and replacing with another, often heifer at first-lactation. The culling rate describes the percentage of cows removed from a herd. It is clear that culling rates is important for managing dairy production. When dairy farm managers cull animal often or too quickly, replacement expenditures are excessive. In the same time, when managers keep cattle for too long, milk production, reproduction, or genetic improvement may be impaired. Thus, the culling rate had been found as an essential element in estimating the economics of dairy herds (Esslemont and Peeter, 1993). In this concept, an overall culling rate of $18 \%$ has been considered as optimal in good dairy herds, although only small percentage of herds achieve that target (Esslemont, 1992). Currently, reproductive failures contribute a substantial proportion of total cow disposals, about $16 \%$ in the US (Freeman, 1984) and $25 \%$ in Canda (Westell et al., 1982). In the same trend the studies of Amand et al. (1980) indicated that reproductive failure was responsible for 16 to $30 \%$ of the total cows disposal. Moreover, past research has consistently estimated optimal herdlevel culling rates ranging from 19 to $29 \%$ (Rogers et al., 1988; Bauer et al., 1993; Stott, 1994 and Jones, 2001).

Long ago, the milk yield is the main economic trait for selection in dairy cattle improvement, as well fat continues improvement in milk yield over the last 50 years this create decline in conception rate (Darwash et al., 1999). Consequently, the deterioration in cow fertility had become a major problem in dairy cattle production.

The genetic antagonistic between production and reproduction traits in the other become more evident in high yielding cows. Consequently the level of the antagonistic is influenced by the role of management (Haile-Mariam et al., 2003 and Kadarmideen et al., 2003). Little genetic improvement could be achieve in the reproductive performance traits however still there are considerable additive genetic variability for exploitation, Oltenacu et al., 1991. The relations between milk production, reproduction and longevity were showed by various reports (Nigm et al., 1988; Sadek, 1994 and Aboul-Ela et al., 2000), indicated that high yielding cows are generally culled earlier and have shorter longevity than low producers.

The objectives of this study were to estimate genetic parameters, breeding values, to determine the percentage of cattle culled within a lactation and conducted to investigate the productive and reproductive performance of culled cows as compared to their contemporaries retained to have subsequent lactations from 1 st to $4^{\text {th }}$ lactations in a herd of Holstein Friesian cows in Hungary. 


\section{MATERIALS AND METHODS}

Records were obtained on productive and reproductive performance over the $1 \underline{\text { st }}$ four lactations of Holstein Friesian cows raised at Mezoheges State Farm Hungary during the period from 1981 to 1990 . Detailed description of breeding policy and management practices was presented previously by Mostafa (2006). Total 6357 records was divided into two sets after their complete that 1 st lactation. Group A comprised 4138 records of cows that were retained in the herd for the 1 st, $2^{\text {nd }}$, $3^{\text {rd }}$ and $4^{\text {th }}$ lactation, with subsequent lactation record, while group B had 2219 records of cows that

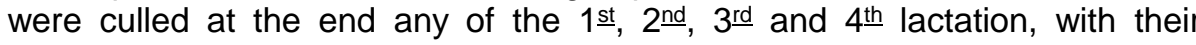
subsequent lactation record.

Traits studied were milk production traits; total milk yield (TMY), 305day milk yield (305-d MY), 305-day fat yield (305-d FY) and persistency of milk yield ( $\operatorname{Pr}$ MY) calculated as described by Mostafa (2006), and reproduction traits; number of services per conception (NSC) and days open (DO).

Separate analysis was performed for each lactation. Least squares means of the two groups (retained or culled) and the differences between them in production, persistency and reproduction traits in the first four lactations were obtained.

Animal models were used for analyses the data in the first lactation. The single-trait derivative-free restricted maximum likelihood (MTDFREML) suite of programs (Boldman et al., 1995) was used for univariate trait analyses. Effects of year and month of calving were assumed to be fixed. Days open and age at first calving (AFC) were included in the model as covariate when TMY, 305-d MY, 305-d FY and Pr MY were analyzed. Milk yield and AFC were included in the model as covariate when reproduction traits were analyzed. And effects of animal and random residual effect considered to be random. The analyses of each trait were conducted using a single trait animal model. The vector presentation of this model is:

$$
\mathrm{Y}=\mathrm{Xb}+\mathrm{Zu}+\mathrm{e}
$$

Where, $Y$ is the vector of observations for all traits, $b$ is a vector of common fixed effects, $u$ is a vector of random genetic effects and $e$ is a vector of residuals and $X$ and $Z$ are incidence matrices relating observations to the fixed and animal effects, respectively.

All genetic estimates were based on 2571 first lactation records. The number of animals and the average number of daughters per sire were 54 and 10 , respectively. Breeding value for studied traits were estimated for each animal in the first lactation and then the comparison between two groups (retained and culled) in different lactations were based on the breeding values for the same trait in the 1st lactation.

Mixed-model equations in the analyses were solved iteratively. Based on the variance of the log-likelihood function values, the convergence criterion was $1 \times 10^{-9}$. In addition, several restarts were necessary until changes in the log-likelihood function values were less than $1 \times 10^{-5}$. Restarts were performed for all analyses, using the final results of the previous 
analysis, in order to locate the global maximum for the log likelihoods. Starting values for variance components for two-trait analyses were obtained from single-trait analyses on individual traits. Best linear unbiased prediction (BLUP) of estimated breeding values (EBVs) were obtained by back-solution using the MTDFREML program for all animals in the pedigree file for singletrait. The standard error for the genetic correlation was calculated as described by Falconer and Mackay (1996).

\section{RESULTS AND DISCUSSION}

\section{Actual means and variation of records:}

Table 1 shows the unadjusted means, standard deviations (S.D) and coefficients of variations (CV\%) for reproduction production, persistency and traits estimated across 1 st four lactations. Means of total milk yield (TMY) being $7197 \mathrm{~kg}$ and 305-day milk yield (305-d MY) being $6974 \mathrm{~kg}$ obtained in this study are close to those reported for Holstein Friesian by Mostafa (1991) and Amin et al. (1997) under Hungarian conditions, while the present findings were higher than those reported on Friesian cattle raised in Egypt by Sadek et al. (1994), Tag El-Dein (1997) and El-Awady (1998). Meanwhile, the estimate means obtained for 305-d MY $(6974 \mathrm{~kg})$ and 305-day fat yield (305d FY) being $255 \mathrm{~kg}$ were also nearly similar to those found by Dematawewa and Berger (1998) being 6929 and $246 \mathrm{~kg}$, respectively, across lactations of Holstein cows. The persistency of milk yield $(\operatorname{Pr} M)$ value across 1 st four lactation was $73 \%$, fall within the range of 69 to $77 \%$ reported by Amin et al. (1977), Mostafa et al. (1999) and Aboul-Ela et al. (2001) on the same breed. The mean of milk production traits in the present study mainly reflects high level of management of Holstein Friesian cows under Hungarian conditions. In general, the differences between the present results and those reported by other researchers could be due to one or more of the following: genotype, management, number of records used in the study and affecting factors considered in the methods of the statistical analysis model.

Table 1: Unadjusted means, standard deviations (S.D) and coefficients of variation (C.V\%) for milk production, reproduction and persistency traits in the first four lactations.

\begin{tabular}{|l|c|c|c|c|}
\hline \multicolumn{1}{|c|}{ Trait } & Abbr. & $\overline{\mathbf{x}}$ & S.D & C.V\% \\
\hline Number of service per conception & NSC & 2.23 & 1.65 & 73.99 \\
Days open (day) & DO & 125.8 & 79.98 & 63.56 \\
Persistency \% & Pr MY & 72.71 & 9.78 & 13.45 \\
Total milk yield (Kg) & TMY & 7197 & 2446.9 & 34.00 \\
Milk yield in 305-days (Kg) & 305-d MY & 6974 & 1749.1 & 25.08 \\
Fat yield in 305-days (Kg) & 305-d FY & 255.0 & 64.3 & 25.28 \\
\hline
\end{tabular}

The mean of days open (DO) across 1 st four lactations (125.8 day) is almost similar to that reported by Aboul-Ela et al. (2001) being 123 day and Oudah et al. (2001) being 124 day on the same breed, but it is lower than that estimated by Dematawewa and Berger (1998) being 169 day and Mostafa (2001) being 185 day across all lactations on Holstein Friesian in Egypt. 
Consequently, the mean of number of services per conception (NSC) across 1 st four lactations (2.23 services) found in the present study is close to that obtained by different authors, Aboul-Ela et al. (2001) being 2.1, Oudah et al. (2001) being 2.0 and Kadarmideen et al. (2003) being 2.0. On the other hand, this mean was slightly higher than that found by Grosshans et al. (1997) 1.5, Dematawewa and Berger (1998) 1.9 and Wall et al. (2003) 1.7. However, it is clearly lower than the value estimated by Mostafa (2001) 2.9 services of Holstein Friesian in Egypt.

Estimates of CV\% values of TMY, 305-d MY and 305-d FY across 1st four lactations ranged from $25-34 \%$ almost similar to estimated by AboulEla et al. (2001) being $24-32 \%$ on Holstein Friesian in Hungary and Mostafa (2001) being $35-37 \%$ on Holstein Friesian in Egypt. While estimate of C.V of $\operatorname{Pr}$ MY across all parities being $14 \%$ is almost similar to estimated value by Aboul-Ela et al. (2001) being $13 \%$ on the same breed.

Estimate of C.V\% were higher in DO and NSC being 64 and $73.99 \%$, respectively, across $1 \underline{\text { st }}$ four lactations, lower than that found by Aboul-Ela et al. (2001) being 46 and 59\%, respectively, on the same breed; and Mostafa (2001) being 59 and 66\%, respectively, on Holstein Friesian in Egypt, which reflect the large individual variations in reproductive performance.

In general, estimates of $\mathrm{CV} \%$ values were lower for Pr MY comparable to $\mathrm{CV} \%$ in milk yield traits which may reflect the role of temporary environment influencing $\operatorname{Pr}$ MY. While higher estimates $\mathrm{CV} \%$ for reproductive traits compared to milk yield traits and Pr MY may indicates that reproductive traits are relatively more influenced by environmental and management of the herd. Consequently, such large CV\% of reproductive traits are indicative for improvement opportunities in these traits.

\section{Genetic parameters:}

Estimates heritability $\left(\mathrm{h}^{2}\right)$ and their standard error (S.E), genetic and phenotypic correlations for productive, reproductive and persistency of milk yield traits obtained in the 1 st lactation are given in Table 2 . The estimate of $\mathrm{h}^{2}$ for TMY $(0.31 \pm 0.05)$ was fall within the range from 0.25 to 0.40 reported by Mostafa (1991). Amin et al. (1997) and Kadarmideen et al. (2000). But it was lower than that reported by Aboul-Ela et al. (2001) $0.54 \pm 0.07$ and Olori et al. (2002) being $0.56 \pm 0.03$ on the same breed. While, estimated $h^{2}$ for 305-d MY $(0.35 \pm 0.05)$ was higher than those reported by Dematawewa and Berger (1998) being 0.30, Mostafa et al. (1999) $0.22 \pm 0.05$, Kadarmideen et al. (2003) being 0.28 and Mostafa (2006) being $0.26 \pm 0.04$. Estimate of $h^{2}$ of 305-d FY was $0.30 \pm 0.04$, almost similar to that obtained by Mostafa (2006) being $0.29 \pm 0.04$ and higher than that found by Dematawewa and Berger (1998) being 0.28 and Kadarmideen et al. (2003) being 0.21 on the same breed, while it was lower than that found by Mostafa et al. (1999) being 0.54 \pm 0.07 . In general, the present estimates indicated that $h^{2}$ value for $305-d M Y$ was higher than $h^{2}$ values for both TMY and 305-d FY ( 0.35 versus 0.31 and 0.30 , respectively) Table 2. A similar trend was also observed by Kadarmideen et al. (2003) found that the values of $h^{2}$ were 0.28 versus 0.21 , Dematawewa and Berger (1998) being 0.30 versus 0.28, Mostafa et al. (1999) being 0.54 versus 0.22 and Mostafa (2006) being 0.29 versus 0.26. In 
general, the moderate $h^{2}$ estimates for milk production traits (e.g. TMY, 305-d MY and 305-d FY) obtained in the present study may be relatively good opportunity for selection for these traits and significant genetic progress would be achieved.

Estimate of $h^{2}$ for Pr MY was $0.10 \pm 0.03$, almost similar values for $h^{2}$ reported by Aboul-Ela (2001) being 0.09, Haile-Mariam et al. (2003) 0.09 and Shalaby (2005) being 0.08 on Holstein Friesian in 1st lactation. However the $\mathrm{h}^{2}$ estimate of $\operatorname{Pr} \mathrm{MY}$ in the present study was lower than those reported by Amin et al. (1997) being 0.22 and Muir et al. (2004) being 0.18, but slightly higher than those reported by Gengler et al. (2001) being 0.05 of Holstein Friesian in USA. It seems from the present findings that among the studied production traits, Pr MY would be the trait would respond least to genetic improvement through selection.

The estimate of $h^{2}$ for days open (DO) was $0.09 \pm 0.03$, which are comparable to other findings in the literature mostly being less than 0.07 , but it could be considered lower than that obtained by Aboul-Ela et al. (2001) being 0.20; Mostafa et al. (2006) being 0.11; Dematawewa and Berger (1998) being 0.12 and Shalaby (2005) being 0.11 . It was slightly higher than that obtained by Amin et al. (1997) being 0.07 and Abdallah and McDaniel (2000) 0.03 , which may be due to differences in data size and statistical model for analysis. Estimate of $\mathrm{h}^{2}$ for number of services per conception (NSC) was $0.12+0.02$, higher than that obtained by Dematawewa and Berger (1998) being 0.03; Kadarmideen et al. (2003) being 0.02 and Wall et al. (2003) being 0.02 . However, it was lower than that of Amin et al. (1997) being 0.14 and Aboul-Ela et al. (2001) being 0.05 on the same breed. In general, because of the rather low $h^{2}$ estimates of reproductive traits improvement of reproductive efficiency through selection would be meaningless, since they are masked to a large extent by the highly variable managerial practices. Thus, improving the management system for two reproductive traits and selection for the high milk yield traits would be effective ways for improving these traits.

Table 2: Estimates heritability \pm S.E (on diagonal) genetic \pm S.E (above diagonal) and phenotypic (below diagonal) correlations among production, reproduction and persistency traits in the first lactation.

\begin{tabular}{|c|c|c|c|c|c|c|}
\hline & NSC & DO & Pr MY & TMY & 305-d MY & 305-d FY \\
\hline NSC & $0.12 \pm 0.03$ & $0.83 \pm 0.10$ & $0.21 \pm 0.15$ & $0.58 \pm 0.12$ & $0.62 \pm 0.16$ & $0.69 \pm 0.19$ \\
DO & 0.65 & $0.09 \pm 0.03$ & $0.12 \pm 0.11$ & $0.91 \pm 0.05$ & $0.86 \pm 0.07$ & $0.88 \pm 0.07$ \\
Pr MY & 0.07 & 0.08 & $0.10 \pm 0.03$ & $0.71 \pm 0.11$ & $0.69 \pm 0.10$ & $0.53 \pm 0.12$ \\
TMY & 0.41 & 0.50 & 0.30 & $0.31 \pm 0.05$ & $0.99 \pm 0.04$ & $0.93 \pm 0.06$ \\
305-d MY & 0.24 & 0.31 & 0.22 & 0.91 & $0.35 \pm 0.05$ & $0.78 \pm 0.09$ \\
305-d FY & 0.32 & 0.33 & 0.21 & 0.45 & 0.46 & $0.30 \pm 0.04$ \\
\hline
\end{tabular}

Table 2 present estimates of genetic $\left(r_{g}\right)$ and phenotypic $\left(r_{p}\right)$ correlations among the production, reproduction and persistency of milk yield traits in the 1st lactation were positive and ranged from 0.21 to 0.99 and from 0.07 to 0.91, respectively, are similar to findings reported by Moore et al. (1991) for 1st parity Holsteins in Canada, Welper (1991) in the US Friesian, Mostafa 


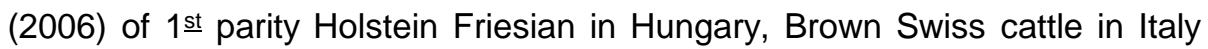
(Santus et al., 1993) and dairy cattle in Australia (Visscher and Goddard, 1995) have reported similar estimates, indicating that correlations among yield traits are relatively stable over standardization procedure, breed or country.

High positive $\mathrm{rg}_{\mathrm{g}}$ Table 2 also was found between DO and NSC $(0.83 \pm$ 0.10 ) is agreement with result by Mostafa (2006) being $0.82 \pm 0.21$ of 1 st lactation on the same breed, indicating evidence for common genetic and physiological mechanisms controlling the two traits. However, a high positive $r_{p} 0.65$ also was found between DO and NSC in agreement with results by Hansen et al. (1983) and Mostafa (2006) being 0.72 on the same breed, because both traits were indicators of less of fertility many management factors, such as estrus detection and the insemination technician contribute to the phenotypic correlation between the two traits.

Estimates of both $r_{g}$ and $r_{p}$ between productive and reproductive traits were positive and medium to high Table 2, ranged from 0.58 to 0.91 and from 0.24 to 0.50 , respectively, in agreement with found by Mostafa (2006). However, $r_{g}$ estimates between production and reproduction traits were positive, in relation to early finding that selection for production alone is expected to lead to a genetic decline in fertility Haile-Mariam et al. (2003), Shalaby (2005) and Mostafa (2006). It is concluded that fertility traits should be incorporated into selection programmers for dairy cows to counteract the antagonistic relationship between milk production and fertility traits. On the same trend, the high $r_{g}$ found in the present study suggest that incorporating reproductive measures in bull indices to hinder the deterioration of reproductive performance in high yielding cows, as proposed by Hermas et al. (1987) and Mostafa (2006).

The $r_{g}$ and $r_{p}$ correlations between Pr MY and both DO and NSC were positive and small ( $r_{g} 0.12$ and 0.21 and $r_{p} 0.08$ and 0.07 , respectively) Table 2. Shalaby (2005) recorded positive $r_{g}$ and $r_{p}$ correlations between $\operatorname{Pr} M Y$ and DO 0.64 and 0.11, respectively. In contrast, Aboul-Ela et al. (2001) reported that $r_{g}$ between $\operatorname{Pr}$ MY and each of DO and NSC were rather poor $(-0.16$ and -0.08 , respectively). Mostafa (2006) found that $r_{g}$ between Pr MY and each of DO and NSC were negative and small $(-0.19$ and -0.17 , respectively) while the $r_{p}$ were -0.78 and 0.13 , respectively, and concluded that the effort to minimize the negative effect of selection for milk yield on fertility and health traits could be obtained by considering Pr MY in breeding program, Solkner and Fuch (1987) reached to similar conclusion.

Table 3 contains a summary of percentage and number of records of Holstein Friesian used in each parity distributed between the two groups, group (A) has subsequent records (Survival to the next lactation) and group (B) has no subsequent records. The percentage of cows culled (group B) from the herd increased gradually between the end of 1 st lactation $(26.3 \%)$ and at the end of 4 th lactation $(49.2 \%)$. A trend of increase in culling rate with advance of lactation has been reported in other studies on dairy cows (e.g. Mostageer et al., 1987; Nigm et al., 1988; Sadek, 1994 and Aboul-Ela et al., $2000)$. The lowest culling rate $(26.3 \%)$ was that the end of the 1 st lactation, this would be expected where as a major reason for disposal were reproductive problems. Also, in later lactations ( $3^{\text {rd }}$ and $4^{\text {th }}$ ) this was 
overtaken 42.2 and $49.2 \%$, respectively, by low milk yield and reproductive as a major reason for culling. However, the culling rate records in the end 1 st lactation $26.3 \%$ were nearly close to that reported by Aboul-Ela et al. (2000) being $27.2 \%$ and Olori et al. (2002) being $29 \%$ on Holstein Friesian cows in Hungary and Ireland, respectively. On the other hand, the percentage of cows retained or survived (group A) to gave the $2^{\text {nd }}$ lactation $(73.7 \%)$ in the present study is nearly similar to that obtained by Aboul-Ela et al. (2000) being $72.8 \%$ on Holstein Friesian in Hungary and Olori et al. (2002) being $71 \%$ in Holstein Friesian in Ireland. But it is lower than that reported by Mostageer (1987) being $85.5 \%$ on Friesian cows in Libya; Sadek (1994) being $96 \%$ on Friesian cow in Egypt.

Table 3: Number and percentages* of records of groups ${ }^{\star \star}$ of cows that were either retained (A) or culled (B) at the end of various lactations.

\begin{tabular}{|c|c|c|c|c|c|}
\hline \multirow{2}{*}{ Group } & \multicolumn{5}{|c|}{ Lactations } \\
\cline { 2 - 6 } & 1st $^{\text {st }}$ & 2nd $^{\text {nd }}$ & $3^{\text {rd }}$ & 4 $^{\text {th }}$ & Total \\
\hline A & $1894(37.7 \%)$ & $1199(63.3 \%)$ & $693(57.8 \%)$ & $352(50.8 \%)$ & $4138(65.1 \%)$ \\
B & $677(26.3 \%)$ & $695(36.7 \%)$ & $506(42.2 \%)$ & $341(49.2 \%)$ & $2219(34.9 \%)$ \\
Total & $2571(100 \%)$ & $1894(100 \%)$ & $1199(100 \%)$ & $693(100 \%)$ & $6357(100 \%)$ \\
\hline
\end{tabular}

* Percentage are between parentheses

** Group A: retained cows with subsequent records.

$B$ : culled cows with no subsequent records or (survival cows from one lactation the next).

Moreover, relatively higher culling rates were observed at the end of the $2^{\text {nd }}$, $3^{\text {rd }}$ and $4^{\text {th }}$ lactations being $36.7,42.2$ and $49.2 \%$, respectively, in the present study (Table 3) as compared to those reported by Esslemont (1992) being $25 \%$ average culling rate in UK, Sadek (1994) being 13.9 and $10.6 \%$ after the end 2nd and 3rd lactations, respectively, in Egypt and Aboul-Ela et al.

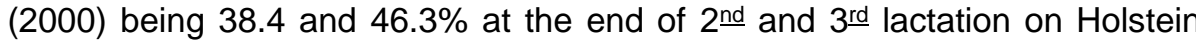
Friesian cows in Hungary. However, the present results indicated that culling rate was $34.9 \%$, while survival rate being $65.1 \%$ at the end 1 st four lactations Table 3. Moreover, actual means for culling in the present study were not available.

The least squares means and standard errors (S.E) of production, persistency and reproductive traits in the two groups ( $A$ and $B$ ) and the difference between the mean of each traits $(D=\bar{X} B-\bar{X} A)$ for the $1 \underline{u}$ four lactations are presented in Table 4. The present results indicate that culled cows (group B) had generally significant higher values of 305-d MY than those retained cows (group A) in the 1st four lactations (Table 4) with the exception of 305-d MY value in the end of $4^{\text {th }}$ lactation, which may be due to practicing selection after the end of $4^{\text {th }}$ lactation, also some cows which have been retained in the herd of such period became more regular calves. However, the difference in 305-d MY between the two groups may be due to the combined effects of the Pr MY, DO and NSC traits which were higher (longer) in the culled cows than retained cows in the 1 st three lactations. The results obtained here agree with that found by Aboul-Ela et al. (2000) on Friesian cows. On the other hand, culled cows (group B) tended to be slightly 
lower values and insignificant of TMY and 305-d FY than those retained cows (group A) in the end 1 st four lactations except the end of 2 nd lactations for the same traits (Table 4). Cows retained for 2, 4 and 5 lactations had greater TMY and 305-d FY by 499, 188 and $800 \mathrm{~kg}, 7,10$ and $17 \mathrm{~kg}$, respectively than those called during $1^{\text {st }}, 3^{\text {rd }}$ and $4^{\text {th }}$ lactations. Higher Pr MY values were obtained for culled cows than retained cows in the end of 1 st two lactations (Table 4) but this was reversed in the end of $3^{\text {rd }}$ and $4^{\text {th }}$ lactations and the difference between two groups was insignificant. Aboul-Ela et al. (2000) reported that higher $\operatorname{Pr}$ MY values were obtained for retained cows in the end of 1 st lactation but this was reversed in the end of 2 nd lactation. On the same trend, cows retained for $4^{\text {th }}$ and $5^{\text {th }}$ lactations had greater $3^{\text {rd }}$ and $4^{\text {th }}$ parity $\operatorname{Pr}$ MY than those called during $3^{\text {rd }}$ and $4^{\text {th }}$ lactations. It is interest to note that cows that were culled for longer DO and increase NSC generally had higher 305-d MY cows retained in the herd (Table 4).

Table 4: Least squares means (X) and standard errors (S.E) of milk production, reproduction and persistency traits of the retained (A) and culled (B) groups of Friesian cows in different lactations.

\begin{tabular}{|c|c|c|c|c|c|c|c|}
\hline Lactation & $\mathbf{N}$ & $\begin{array}{c}\text { Group A } \\
X \pm S . E\end{array}$ & $\mathbf{N}$ & $\begin{array}{c}\text { Group B } \\
X \pm S . E\end{array}$ & $\begin{array}{l}\text { Difference } \\
D=\left(\mathbf{X}_{B}-\mathbf{X}_{A}\right)\end{array}$ & T value & $P>$ value \\
\hline \multicolumn{8}{|c|}{ Number of services/conception (NSC) } \\
\hline $1 \underline{\text { st }}$ & 1855 & $2.1 \pm 0.04$ & 514 & $2.2 \pm 0.07$ & +0.1 & 1.2 & $0.25^{\text {N.S }}$ \\
\hline $2 \underline{\text { nd }}$ & 1184 & $2.2+0.05$ & 566 & $2.6+0.08$ & +0.4 & 4.2 & $0.0001^{* *}$ \\
\hline $3 \underline{\text { rd }}$ & 682 & $2.1+0.06$ & 390 & $2.6+0.09$ & +0.5 & 9.4 & $0.0001^{* *}$ \\
\hline $4^{\text {th }}$ & 341 & $2.2+0.09$ & 241 & $2.4+0.12$ & +0.2 & 1.3 & $0.19^{\text {N.S }}$ \\
\hline \multicolumn{8}{|c|}{ Days open (DO, day) } \\
\hline $1 \underline{s t}$ & 1853 & $135+1.9$ & 512 & $130+3.9$ & -5 & -1.3 & $0.20^{\text {N.S }}$ \\
\hline $2 \underline{\text { nd }}$ & 1179 & $121+2.3$ & 565 & $136+3.6$ & +15 & 3.5 & $0.0005^{* *}$ \\
\hline $3 \underline{\text { rd }}$ & 680 & $112+2.8$ & 387 & $123+4.1$ & +11 & 2.3 & $0.024^{*}$ \\
\hline $4^{\text {th }}$ & 340 & $114+3.8$ & 239 & $116+4.6$ & +2 & 0.3 & $0.76^{\text {N.S }}$ \\
\hline \multicolumn{8}{|c|}{ Persistency (Pr MY\%) } \\
\hline $1 \underline{s t}$ & 1715 & $76.5 \pm 0.51$ & 379 & $76.6+0.22$ & +0.1 & 0.18 & $0.8566^{\text {N.S }}$ \\
\hline $2 \underline{\text { nd }}$ & 1078 & $71.0+0.30$ & 386 & $71.6+0.45$ & +0.6 & 1.10 & $0.2532^{\text {N.S }}$ \\
\hline $3 \underline{\text { rd }}$ & 623 & $69.9+0.38$ & 268 & $69.0+0.58$ & -0.9 & -1.2 & $0.2406^{\text {N.S }}$ \\
\hline $4^{\text {th }}$ & 302 & $68.9 \pm 0.55$ & 160 & $68.3 \pm 0.65$ & -0.6 & -0.7 & $0.5013^{\text {N.S }}$ \\
\hline \multicolumn{8}{|c|}{ Total milk yield $(\overline{T M Y}, \mathrm{Kg})$} \\
\hline $1 \underline{\text { st }}$ & 1891 & $7043 \pm 49.5$ & 604 & $6544 \pm 108.3$ & -499 & -4.2 & $0.0001^{* *}$ \\
\hline $2 \underline{\text { nd }}$ & 1204 & $7526+63.8$ & 634 & $7629 \pm 119.2$ & +103 & 0.8 & $0.4438^{\text {N.S }}$ \\
\hline $3 \underline{\text { rd }}$ & 695 & $7477 \pm 77.9$ & 440 & $7289 \pm 141.5$ & -188 & -1.2 & $0.2429^{N . S}$ \\
\hline $4^{\text {th }}$ & 347 & $7506 \pm+109.7$ & 289 & $6706 \pm 166.7$ & -800 & -0.4 & $0.0001^{\text {N.S }}$ \\
\hline \multicolumn{8}{|c|}{ 305-day milk yield (305-d MY, Kg) } \\
\hline $1 \underline{\text { st }}$ & 1256 & $6560 \pm 35.4$ & 428 & $6806 \pm 76.6$ & +246 & 2.9 & $0.0037^{*}$ \\
\hline $2 \underline{\text { nd }}$ & 1120 & $7179+49.9$ & 464 & $7459 \pm 92.5$ & +280 & 2.7 & $0.0078^{\star}$ \\
\hline 3 rd & 652 & $7194 \pm 65.4$ & 306 & $7332 \pm 124.5$ & +138 & -2.2 & $0.0316^{*}$ \\
\hline $4^{\text {th }}$ & 324 & $7200 \pm 87.5$ & 214 & $7020 \pm 165.6$ & -180 & -1.0 & $0.3377^{\text {N.S }}$ \\
\hline \multicolumn{8}{|c|}{ 305-day fat yield (305-d FY, Kg) } \\
\hline $1 \underline{\text { st }}$ & 1737 & $246 \pm 1.3$ & 438 & $239 \pm 2.8$ & -7 & -2.3 & $0.0250^{*}$ \\
\hline 2 nd & 1127 & $264 \pm 1.9$ & 506 & $269 \pm 3.4$ & +5 & 1.2 & $0.2361^{\text {N.S }}$ \\
\hline $3 \underline{\text { rd }}$ & 654 & $266+2.2$ & 568 & $256+4.1$ & -10 & -2.2 & $0.0316^{\star}$ \\
\hline $4^{\text {th }}$ & 397 & $259 \pm 3.2$ & 243 & $242+5.4$ & -17 & -2.7 & $0.0074^{*}$ \\
\hline
\end{tabular}


In the present study culled cows had slightly longer DO than retained cows in the end of 1 st four lactations (Table 4) and the difference between two groups was significant, except in the end of 1 st and $2 \underline{\text { nd }}$ lactations. On the same trend, cows retained in the herd for $2^{\text {nd }}$, $3^{\text {rd }}$ and $4^{\text {th }}$ lactations conceived earlier during 1 st lactation $(15,11$ and 2 days) fewer DO, respectively, than those culled during 1 st lactation. However, the difference values of DO ranging from 2 to 15 day in various lactations can be partly attributed to lower conception rate with NSC value being 0.1 to 0.5 services in culled cows (Table 4), AboulEla et al. (2000) reported that culled cows had longer DO as well as higher values of NSC than retained cows and the differences in DO and NSC ranging from 15 to 53 day and 0.1 to 0.5 services, respectively, in the end 1 st four lactations. However, culled cows had higher value of NSC than retained cows in the end 1 1 t four lactations and the difference between two groups were significant, except in the end 1 st and $4^{\text {th }}$ lactations and non-significant (Table 4). On the same trend, cows retained for $2^{\text {nd }}, 3^{\text {rd }}$, $4^{\text {th }}$ and $5^{\text {th }}$ lactations had lower 1 1 st, 2 nd, 3 rd and $4^{\text {th }}$ lactations NSC by $0.1,0.4,0.5$ and 0.2 services than those culled cows during $1^{\text {st }}, 2 \frac{\text { nd }}{}, 3$ rd and $4^{\text {th }}$ lactations, respectively.

Table 5 contains a summary of mean, standard deviations (S.D), minimum, maximum, range of estimated breeding values of cows (EBVs) and difference between retained and culled cows groups for EBVs of production, persistency and reproductive traits in the end of 1 st four lactations. The range in EBVs of cows of 1 st four lactations for TMY for both retained (survival) and culled cows was from 4140 to $7727 \mathrm{~kg}$ and from 4008 to $7654 \mathrm{~kg}$, respectively. Regarding the means of EBVs obtained for TMY of retained cows had significant lower values than culled cows in the end $1^{\text {st }}$ and $4^{\text {th }}$ lactations, while culled cows had higher range of EBVs than retained cows in the $2^{\text {nd }}$ and $3^{\text {rd }}$ lactations and the difference between them were significant. The range in EBVs of cows of 1st four lactations for 305-d MY for both retained and culled cows were from 3962 to $5572 \mathrm{~kg}$ and from 3863 to 5280 $\mathrm{kg}$, respectively. However, regarding the EBVs and S.D obtained for of $1 \underline{\mathrm{st}}$ and $2^{\text {nd }}$ lactations, may be due to a major reason for culling cows by reproductive disorders, while in the end of $3^{\text {rd }}$ and $4^{\text {th }}$ lactations culled cows were significant higher values than retained cows for 305-d MY, may be due to a major reason for culling cows by low milk production. However, for retained culled cows groups the S.D of EBVs of 305-d MY increased from the end $1 \underline{\text { st }}$ to end 2 nd lactation, while it was dropped from the end $3 \underline{\text { rd }}$ to end 4 th lactation (Table 5). Also, the mean of EBVs for 305-d MY of retained cows was increased with advance of parity, while in culled cows un-similar trend was shown Table 5. The range in EBVs of cows of 1 st four lactations for 305d FY for both retained and culled cows were from 121 to $192 \mathrm{~kg}$ and from 121 to $169 \mathrm{~kg}$, respectively. Also, the present study indicated that the range of EBVs for 305-d FY of retained cows were significant higher values than culled cows in the 1 st four lactations (Table 5), except in the end 4 th lactation. Moreover, the values of EBVs of 305-d FY of retained cows were higher than culled cows in the end $1 \underline{\text { st }}$ two lactations and it was reverses in the end $3 \stackrel{\text { rd }}{\text { d }}$ and $4^{\text {th }}$ lactations. The range in EBVs of cows of 1 st four lactations for $\operatorname{Pr}$ MY for both retained and culled cows were from 7.9 to $9.3 \%$ and from 7.2 to $8.4 \%$, respectively. 
J. Agric. Sci. Mansoura Univ., 34 (9), September, 2009

T5

9399 
While, regarding the range of EBVs obtained in the present study for $\operatorname{Pr} M Y$ of retained cows were significant lower than culled cows in the end 1 st four lactations (Table 5), except in the end 3 rd lactation the difference between them was non-significant. Also, the mean of EBVs of retained cows was increased with advance the parity, while for culled cows it was had nonsimilar trend Table 5.

The range in EBVs of cows of 1 st four lactations for both retained and culled cows were from 2.6 to 2.9 and from 1.8 to 2.7 services, respectively. Regarding the EBVs obtained for NSC, retained cows had significant lower values than culled cows in the end 1 1 t four lactations. The range in EBVs of cows of 1 st four lactations for DO for both retained and culled cows were from 69 to 110 day and from 51 to 109 day, respectively. However, the present study indicated that the EBVs for DO of retained cows were lower value than culled cows in the first four lactations and the difference between two groups for EBVs were significant.

\section{CONCLUSIONS}

It can be concluded from the present study that, in general, the range in EBVs of cows for all traits studied for both retained and culled cows were wide, suggesting to the effective scope for selection. The present findings indicated that the EBVs for reproductive, milk production and persistency traits were higher value for culled cows than retained cows. These results showed that the culled cows have lower reproductive performance and higher milk production traits than those retained in the herd. Thus, the need to give special attention to reproductive management of high yielding dairy cows and thus, increase their longevity. Culling decisions high yielding cows mean loss of the super genes of this animal from the population. At the culling time start the economic losses in one hand and the benefit genes in the other hand. Thus the herd manager must be given more attention to this decision. Therefore, good breeding must be used to choice the culling decisions animal. Moreover, culling decisions have an important influence on the economic performance of the dairy but are must be based on the EBVs for economic traits.

\section{REFERENCES}

Abdallah, J.M. and B.T. McDaniel (2000). Genetic parameters and trends of milk, fat, days open, and body weight after calving in North Carolina experimental herds. J. Dairy Sci. 83: 1364.

Aboul-Ela, M.B.; M.A. Mostafa and N.A. Shalaby (2001). Association between productive and reproductive performance in Holstein herd in Hungary. J. Agric. Sci. Mansoura Univ., 26(1): 207-216.

Aboul-Ela, M.B.; N.A. Shalaby and M.A. Mostafa (2000). Comparison of productive and reproductive performance between culled cows and their contemporaries retained in herd of Friesian cattle. J. Agric. Sci. Mansoura Univ., 25(12): 7569 - 7575. 
Amin, A.A.; S. Töth and T. Gere (1997). Relationship between daily milk yield and persistency of Hungarian Holstein-Friesian through selection index and sub-indices. Reprod. Dom. Anim., 32: 207 - 212.

Arnand, S.; J. Moxley; B. Downy and B. Kennedy (1980). Genetic and performance of cows culled for reproduction reasons. Can. J. Anim. Sci., 60: 549 (Abstr.).

Bauer, L.; G. Mumey and W. Lohr (1993). Longevity and genetic improvement issues in replacing dairy cows. Can. J. Agric. Econ., 41: $71-80$.

Boldman, K.G., L.A. Kriese, L.D. Van Vleck, C.P. Van Tassell and S.D. Kachman (1995). A manual for use of MTDFREML. USDA, ARS, Clay Center, NE.

Brotherstone, S.; R.E. Veerkamp and W.G. Hill (1997). Genetic parameters for a simple predictor of the lifespan of Holstein Friesian dairy cattle. Livestock Production Science, 40: 115 - 122.

Darwash, A.O.; G.E. Lamming and J.A. Woolliams (1999). The potential for identifying heritable endocrine parameters associated with fertility in postpartum dairy cows. Anim. Sci. 68: $333-347$.

Dematawewa, C.M.B. and P.J. Berger (1998). Genetic and phenotypic parameters for 305-day yield, fertility and survival in Holsteins. J. Dairy Sci., 81(10): $2700-2709$.

El-Awady, H.G. (1998). Genetic analysis of reproductive and productive performance of Friesian Herds. Ph.D. Thesis, Fac. Of Agric., Kafr ElSheikh, Tanta Univ., Egypt.

Esslemont, R.J. (1992). An index of dairy herd fertility. Farm management, Vol. 8 No. 1, Spring 1992.

Esslemont, R.J. and E.J. Peeter (1993). The scope for raising margins in dairy herds by improving fertility and health. Br. Vet. J., 149: 538.

Falconer, D.S. and T.O.Mackay (1996). Introduction to Quantitative Genetic. $4^{\text {th }}$ Edition, Longman, Harlow UK.

Freeman, A.E. (1984). Sire selection. Secondary traits: sire evaluation and the reproductive complex. J. Dairy Sci., 67: $449-458$.

Gengler, N.; A. Tijani, G.R. Wiggans and J.C. Philpot (2001). Indirect estimation of (Co) variance functions for test-day yields during first and second lactations in the United States. J. Dairy Sci., 84, Available, http./www adsa org Accessed Feb. 27, 2001.

Grosshans, T., Z.Z. Xu, L.J. Burton, D.L. Johnson and K.L. Macmillan (1997). Performance and genetic parameters for fertility of seasonal dairy cows in New Zeiland. Livest. Prod. Sci., 51: 44(41-51).

Haile-Mariam, M.; P.J. Bowman and M.E. Goddard (2003). Genetic and environmental relationships among calving interval, survival, persistency of milk yield and somatic cell count in dairy cattle. Livest. Prod. Sci., 80: 189.

Hansen, L.B., A.E. Freeman and P. J. Berger (1983). Yield and fertility relationships in dairy cattle. J. Dairy Sci., 66: $293-305$.

Hermas, S.A.; C.M. Young and J.W. Rust. (1987). Genetic relationships and additive genetic variation of productive and reproductive traits in Guernsey dairy cattle. J. Dairy Sci., 70: 1252 - 1257. 
Jones, B. (2001). Cow longevity and optimal culling decisions in dairy operations. P. $62-66$ in 2001 Arlington Dairy Days Proc., University of Wisconsin-Madison Department of Animal Science.

Kadarmideen, H.N.; R. Thompson and G. Simm (2000). Linear and threshold model genetic parameters for disease, fertility and milk production in dairy cattle. Anim. Sci. 71: 411.

Kadarmideen, H.N.; R. Thompson, M.P. Coffey and N.A. Kossaibati (2003). Genetic parameters and evaluation from single-and multiple-trait analysis of dairy cow fertility and milk production. J. Livest. Prod. Sci., 81: 183.

Moore, R.K.; B.W. Kennedy, L.R. Schaeffer and J.E. Moxely (1991). Relationship between age and body weight and production in first lactation Ayrshires and Holsteins. J. Dairy Sci., 74: $269-278$.

Mostafa, M.A. (1991). Genetic and non-genetic factors affecting production and reproduction traits in dairy cattle. Ph.D. Thesis, MTA, Budapest, Hungary.

Mostafa, M.A. (2001). Relationships between milk production and postpartum reproductive performance in Friesian cows. J. Agric. Sci., Mansoura Univ., 26(4): 1909.

Mostafa, M.A. (2006). Genetic evaluation of milk production and reproduction traits in Holstein-Friesian raised in Hungary using single and multi-trait animal model analyses. J. Agric. Sci. Mansoura Univ., 31(10): 6217 6231.

Mostafa, M.A.; E.Z.M. Oudah and N.A. Shalaby (1999). Estimation of genetic parameters and sire transmitting abilities for some milk production traits in a herd of Holstein Friesian cattle raised in Hungary. J. Agric. Sci. Mansoura Univ., 24(10): 5475 - 5496.

Mostageer, A.; M.A. Morsy; A.A. Nigm and R.R. Sadek (1987). The performance of some European cattle breeds in adverse environments. J. of Animal Breeding and Genetics, 104: 206 - 212.

Muir, D.L.; J. Fatehi and L.R. Schaeffer (2004). Genetic relationships between persistency and reproductive performance in first-lactation Canadian Holsteins. J. Dairy Sci., 87: 3029.

Nigm, A.A.; R.R. Sadek and N.S. Rashad (1988). Culling and lactation performance in Brown Swiss and crossbred cattle in Egypt. In: Ruminant Production in the Dry Subtropics: Constraints and Potentials. Pudoc Wageningen, the Netherlands. Pp. $133-140$.

Olori, V.E.; T.H.E., Meuwissen and R.F. Veerkamp (2002). Calving interval and survival breeding values as measure of cow fertility in a pasturebased production system with seasonal calving. J. Dairy Sci., 85: 689.

Oltenacu, P.A.; A. Frick and B. Lindhe (1991). Relationship of fertility to milk yield in Swedish cattle. J. Dairy Sci., 74: $264-268$.

Oudah, El. Z.M.; N.A. Shalaby and M.A. Mostafa (2001). Genetic and nongenetic factors affecting days open, number of services per conception and age at first calving in a herd of Holstein-Friesian cattle. Pakistan J. Biol. Sci., (4): 740. 
Rogers, G.; J. van Arendonk and B. McDaniel (1988). Influence of production and prices on optimal culling rates and annualized net revenue. $\mathrm{J}$. Dairy Sci., 71 : 3453 - 3462.

Sadek, R.R. (1994). Lactation performance of retained and culled Friesian cows in commercial farms in Egypt. Egypt J. Anim. Prod., 31: 205 212.

Santus, E.C.; R.W. Everett, R.L. Quass and D.M. Galton (1993). Genetic parameters of Italian Brown Swiss for levels of herd yield. J. Dairy Sci., 76: $3594-3600$.

Shalaby, N.A. (2005). Genetic evaluation for milk production, reproduction traits and persistency of lactation using single-and two-trait animal model analyses for Friesian cows in commercial herds in Egypt. J. Agric. Sci. Mansoura Univ., 30(7): 3637.

Solkner, J. and W. Fuchs (1987). A comparison of different measures of persistency with special respect to variation of test day milk yields. J. livest. Prod. Sci., 16: 305.

Stott, A. (1994). The economic advantage of longevity in the dairy cow. J. Agric. Econ., 45: 113 - 122.

Tag El-Dein, M.A. (1997). Studies on cattle, phenotypic and genetic parameters of some performance traits in Friesian cattle. Ph.D. Thesis, Fac. of Agric. Alex. Univ., Egypt.

Visscher, P.M. and M.E. Goddard (1995). Genetic parameters for milk yield, survival, workability and type traits for-Australian dairy cattle. J. Dairy Sci., 78: $205-220$.

Wall, E., S. Brotherstone, J.A. Woolliams, G. Banos and M.P. Coffey (2003). Genetic evaluation of fertility using direct and correlated traits. J. Dairy Sci., 86: 4093.

Welper, R.D. (1991). Estimation of variance components and response to selection for milk composition in Holsteins, including lactose and somatic cell score. Ph.D. Diss., lowa State Univ., Ames.

Westell, R.A.; E.B. Burnside and L.R. Schaeffer (1982). Evaluation of Canadian Holstein-Friesian sires on disposal reasons of their daughters. J. Dairy Sci. 65: 2336 - 2372.

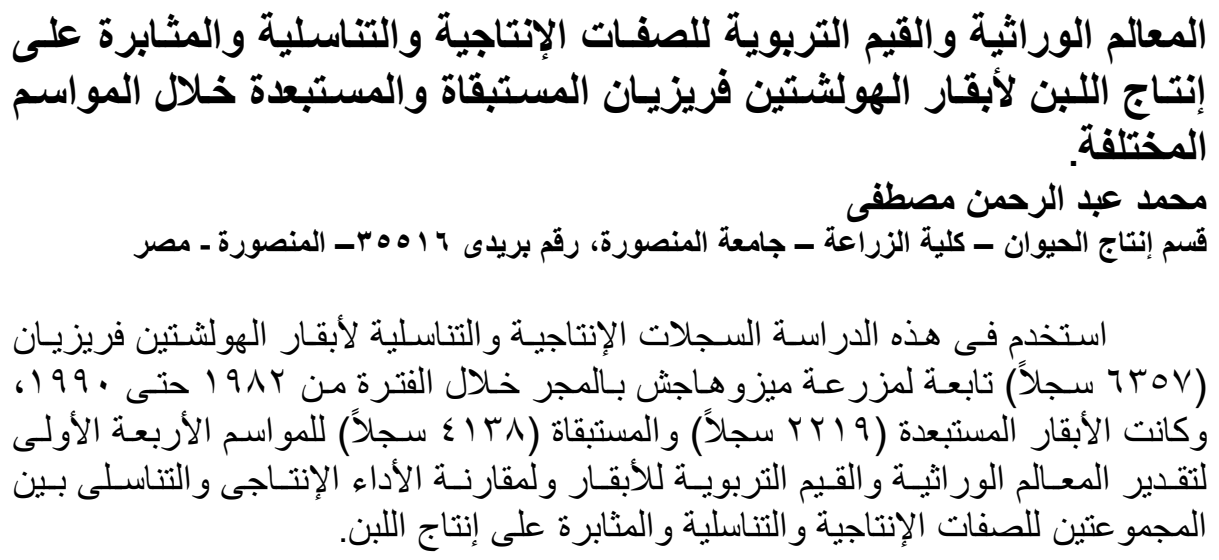




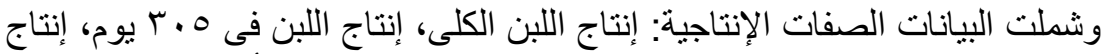

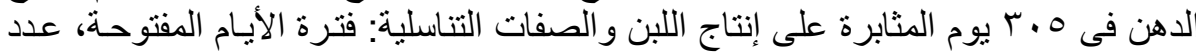

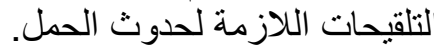

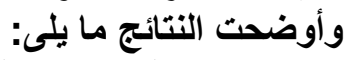

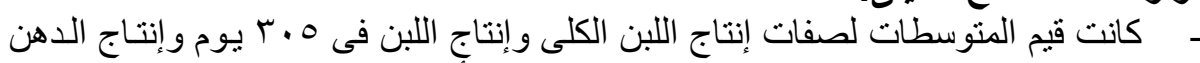

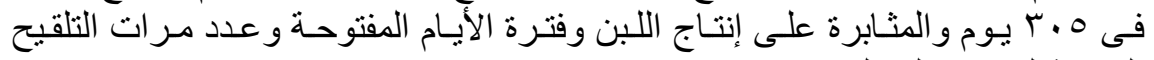

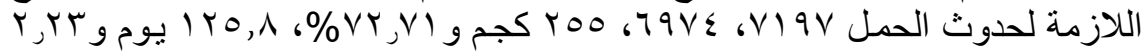

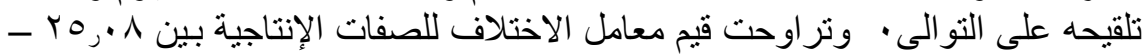

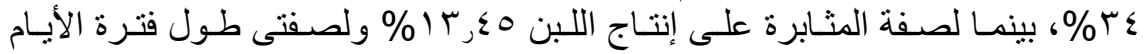

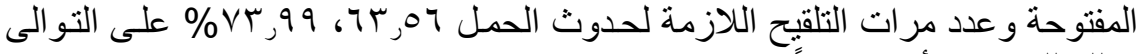
وذللك للمو اسم الأربعة معبـاً.

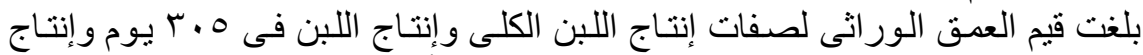

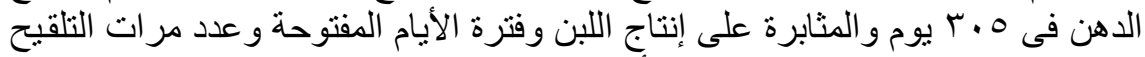

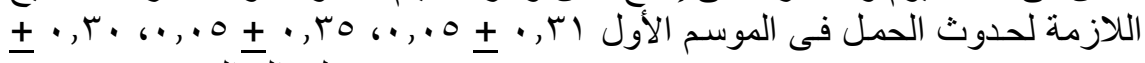

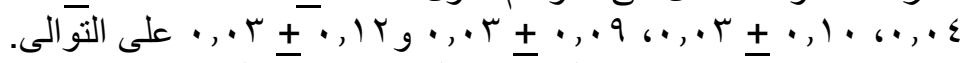

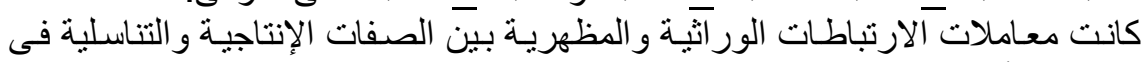

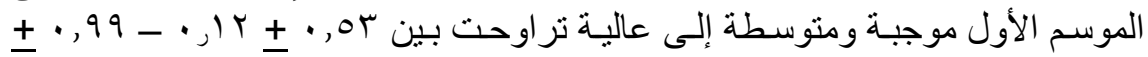

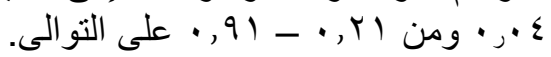

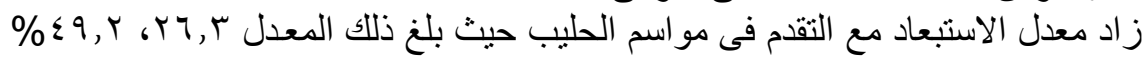

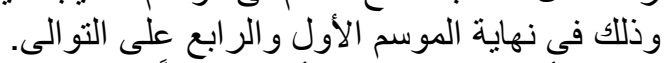

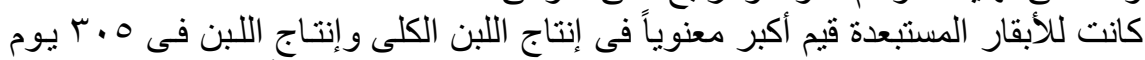

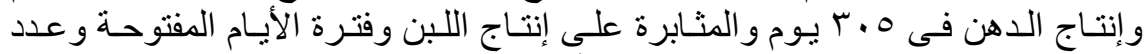
التلقيحات اللازمة لحدوث الحثب الحمل مقارنة بالأبقار المستبقاة.

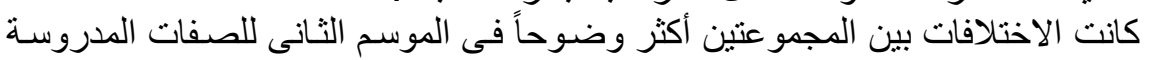

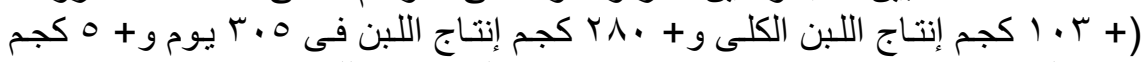

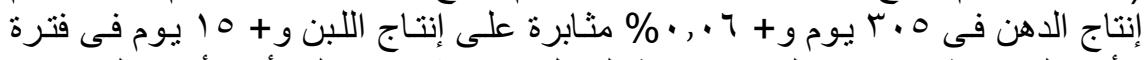

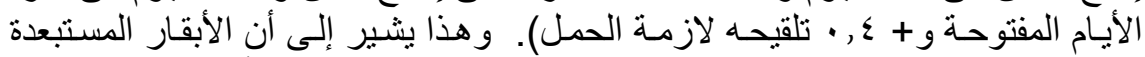

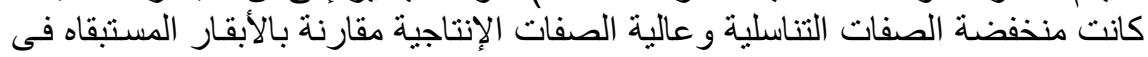

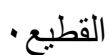

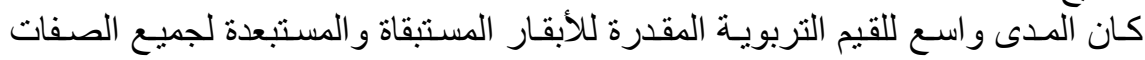

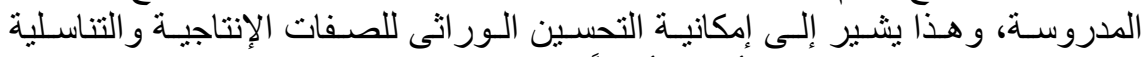

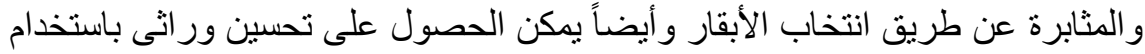

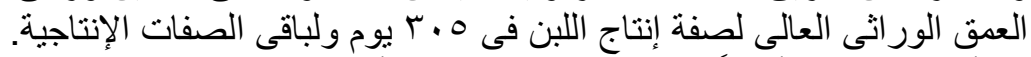

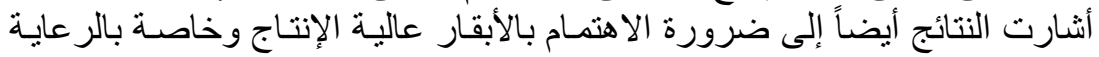

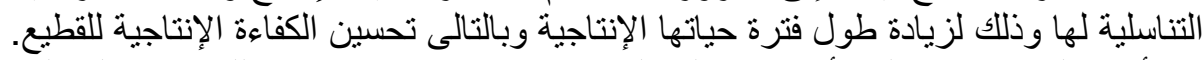

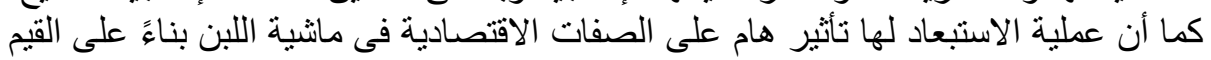
التربوية لهذه الصفات الانبعاد 
Table 5: Mean, standard deviations (S.D), minimum maximum and range of estimated breeding values (EBVs) of milk production, reproduction and persistency of lactation traits of the retained (A) and culled (B) groups of Friesian cows in different lactations.

\begin{tabular}{|c|c|c|c|c|c|c|c|c|c|c|}
\hline \multirow[t]{2}{*}{ Lactation } & \multicolumn{5}{|c|}{ Retained group (A) } & \multicolumn{5}{|c|}{ Culled group (B) } \\
\hline & Mean & S.D & Minimum & Maximum & Range & Mean & S.D & Minimum & Maximum & Range \\
\hline \multicolumn{11}{|c|}{ NSC } \\
\hline 1 st & -0.09 & 0.32 & -1.26 & 1.64 & 2.90 & -0.03 & 0.19 & -0.77 & 1.13 & $1.90^{* *}$ \\
\hline $2^{\text {nd }}$ & -0.13 & 0.35 & -1.04 & 1.64 & 2.68 & -0.02 & 0.27 & -1.26 & 1.40 & $2.66^{\star *}$ \\
\hline $3^{\text {rd }}$ & -0.21 & 0.35 & -0.09 & 1.64 & 2.63 & -0.03 & 0.32 & -1.04 & 1.31 & $2.35^{\star \star}$ \\
\hline $4^{\text {th }}$ & -0.24 & 0.36 & 0.99 & 1.64 & 2.63 & -0.17 & 0.33 & -0.94 & 0.89 & $1.83^{\star \star}$ \\
\hline \multicolumn{11}{|c|}{ DO (day) } \\
\hline $1^{\text {st }}$ & -1.62 & 9.98 & -54.15 & 55.97 & 110.12 & -2.17 & 8.22 & -24.86 & 42.69 & $67.55^{\text {N.S }}$ \\
\hline $2^{\text {nd }}$ & -2.02 & 10.19 & -35.40 & 55.97 & 91.37 & -0.91 & 9.59 & -54.15 & 54.35 & $108.50^{*}$ \\
\hline $3^{\text {rd }}$ & -3.45 & 9.96 & -35.40 & 33.05 & 68.05 & -0.07 & 10.18 & -24.84 & 55.97 & $80.81^{* *}$ \\
\hline $4^{\text {th }}$ & -4.21 & 10.81 & -35.40 & 33.05 & 68.05 & -2.66 & 9.69 & -22.58 & 28.24 & $50.82^{*}$ \\
\hline \multicolumn{11}{|c|}{ TMY (Kg) } \\
\hline 1 st & -23.2 & 836.34 & -2535 & 5192 & 7727 & 23.3 & 762.29 & -1625 & 3134 & $4759^{\star *}$ \\
\hline $2^{\text {nd }}$ & -137.3 & 811.69 & -2535 & 3433 & 5968 & 173.6 & 842.19 & -2462 & 5192 & $7654^{* *}$ \\
\hline $3^{\text {rd }}$ & -209.6 & 729.35 & -2229 & 1996 & 4225 & -38.5 & 903.92 & -2535 & 3433 & $5968^{* *}$ \\
\hline $4^{\text {th }}$ & -264.8 & 707.00 & -2144 & 1996 & 4140 & -152.5 & 748.48 & -2229 & 1779 & $4008^{*}$ \\
\hline \multicolumn{11}{|c|}{ 305-d MY (Kg) } \\
\hline $1^{\text {st }}$ & -48.4 & 748.81 & -2658 & 2914 & 5572 & 198.73 & 516.96 & -1826 & 2037 & $3863^{\star *}$ \\
\hline $2^{\text {nd }}$ & -134.8 & 773.37 & -2658 & 2622 & 5280 & 100.68 & 679.58 & -2011 & 2914 & $4925^{\star *}$ \\
\hline $3^{\text {rd }}$ & -204.5 & 721.88 & -2330 & 2076 & 4406 & -39.30 & 830.04 & -2658 & 2622 & $5280^{* *}$ \\
\hline $4^{\text {th }}$ & -262.8 & 673.57 & $\begin{array}{l}-2139 \\
\end{array}$ & 1823 & 3962 & -145.40 & 765.07 & -2330 & 2076 & $4406^{*}$ \\
\hline \multicolumn{11}{|c|}{ 305-d FY (Kg) } \\
\hline 1st & -37.78 & 260.92 & -918.2 & 999.4 & 191.76 & 33.45 & 194.55 & -55.07 & 67.12 & $121.19^{* \star}$ \\
\hline $2^{\text {nd }}$ & -72.18 & 25.53 & -91.82 & 99.94 & 191.76 & 21.56 & 25.99 & -73.30 & 95.37 & $168.67^{* *}$ \\
\hline $3^{\text {rd }}$ & -89.46 & 23.62 & -67.85 & 99.94 & 167.79 & -48.51 & 27.79 & -91.82 & 74.64 & $166.46^{*}$ \\
\hline $4^{\text {th }}$ & -11.71 & 22.17 & -67.85 & 52.99 & 120.84 & -6.09 & 24.73 & -61.55 & 99.94 & $161.49^{* *}$ \\
\hline \multicolumn{11}{|c|}{ Pr MY \% } \\
\hline 1 st & -0.15 & 1.42 & -5.10 & 4.20 & 9.30 & 0.27 & 1.20 & -3.00 & 4.17 & $7.17^{\star}$ \\
\hline $2^{\text {nd }}$ & -0.25 & 1.51 & -5.10 & 3.84 & 8.94 & 0.02 & 1.25 & -4.19 & 4.20 & $8.39^{* *}$ \\
\hline $3^{\text {rd }}$ & -0.27 & 1.53 & -4.78 & 3.84 & 8.62 & -0.22 & 1.47 & -5.10 & 3.15 & $8.25^{\mathrm{N} . \mathrm{S}}$ \\
\hline $4^{\text {th }}$ & -0.37 & 1.57 & -4.06 & 3.84 & 7.90 & -0.17 & 1.49 & -4.78 & 3.45 & $8.23^{*}$ \\
\hline
\end{tabular}


Mostafa, M.A.

9406 